European journal of American studies

\title{
Railroad Workers, Civilization and Communism: the Young Men's Christian Association on the Interwar Polish Frontier
}

Sylwia Kuźma-Markowska

\section{OpenEdition}

\section{Journals}

Electronic version

URL: https://journals.openedition.org/ejas/13718

DOI: $10.4000 /$ ejas. 13718

ISSN: 1991-9336

Publisher

European Association for American Studies

Electronic reference

Sylwia Kuźma-Markowska, "Railroad Workers, Civilization and Communism: the Young Men's

Christian Association on the Interwar Polish Frontier", European journal of American studies [Online],

13-3 | 2018, Online since 23 January 2019, connection on 08 July 2021. URL: http://

journals.openedition.org/ejas/13718; DOl: https://doi.org/10.4000/ejas.13718

This text was automatically generated on 8 July 2021.

Creative Commons License 


\title{
Railroad Workers, Civilization and Communism: the Young Men's Christian Association on the Interwar Polish Frontier
}

\author{
Sylwia Kuźma-Markowska
}

1 For the recently reborn Poland the post-World War I years brought havoc, disease and enduring military conflict. Regaining independence after more than a century of partitions, Poland struggled with typhus and against Soviet Russia. The country's inhabitants suffered hunger and malnutrition; many of them faced homelessness while returning to Poland after several years of being forced migrants or refugees. The situation of the devastated and disease-ridden country triggered humanitarian responses from Western Europe and North America. Among several humanitarian organizations that assisted the postwar Poland was the Young Men's Christian Association of the United States (YMCA, often named simply the Y).

2 This article seeks to present and analyze one of the aspects of the YMCA's work in Poland: the initiatives for railroad workers from eastern frontier towns and cities. Focusing on the efforts that the organization undertook on the territory commonly referred to as the "Polish borderland" (Kresy), I show that for the leaders of the Y the work among the railway employees was of utmost political and civilizational importance. There were several reasons why the YMCA became involved in the railroad work on the eastern Polish borderlands. One of them was the looming threat of communism from neighboring Russia, another-the American Y leaders' mythic perceptions of the U.S. moving frontier, which prompted them to adapt the American discourse on civilization to the Polish political and social situation. Using archival documents and recollections of Americans involved in the Y's activities on the eastern Polish frontier I present how the perception of the Polish borderland by Y's secretaries was greatly influenced by myths deeply embedded in American culture. Drawing on the contemporary Polish press reports as well as writings of local collaborators of the 
YMCA, I also describe the reaction of Polish public opinion to the Y's undertakings on the Polish frontier.

3 The article situates the Polish case in a broader context of YMCA international activism and poses questions regarding the specificities of the Y's undertakings in interwar Poland. The research on the involvement of the $Y$ in post-World War I countries of Central and Eastern Europe has so far stressed mainly the YMCA's sport initiatives, its service to the soldiers and veterans as well as the organization's role in the rebuilding of the then newly (re)born countries of the region. ${ }^{1} \mathrm{~A}$ focus on the Y's work for railroad workers expands the knowledge and understanding of the organization's overseas activism and sheds light on the circumstances of transferring American cultural concepts to interwar Europe. The story of the Y's involvement in the work on the Polish frontier also confirms the organization's adaptability and flexibility in its international undertakings which has been emphasized by such YMCA historians as Matthew L. Miller. $^{2}$

4 In the first decades of the twentieth century the YMCA was one of the largest American service organizations. Since its inception, it spread not only throughout the Englishspeaking world but also into several other countries of Europe, North America and Asia. Established in Great Britain in 1844 as an evangelical organization, the YMCA expanded into the United States in 1851. During the post-Civil War decades the organization was setting up municipal branches and erecting buildings in many American cities. The $\mathrm{Y}$ branches offered dorms, educational activities, and "wholesome" entertainment. In the second half of the nineteenth century, the organization generally directed its efforts to male middle-class city dwellers. The $Y$ emphasized its religious character and devoted much energy to such activities as Bible study. ${ }^{3}$

5 At the turn of the twentieth century the YMCA reoriented itself, reacting to such changes in American society as extensive industrialization, rapid urbanization, or massive immigration. The power and authority of white middle class men-the main targets of the Y's efforts-began to falter, challenged by immigrants, working class men and the women's suffrage movement. As a response to these changes, the YMCA downplayed the evangelical element in its activities and began to emphasize a symmetrical development of young men who were to enhance their minds and body fitness by participation in social clubs and sports activities that became the pinnacle of the Y's program. ${ }^{4}$ In the United States, as well as in Great Britain, the Y's secretaries and members embraced a new model of manliness: Muscular Christianity that combined religiosity with physical strength and stamina that were to characterize young men exercising in the Y's gymnasia. ${ }^{5}$ Concentrated previously on white middle class men, the YMCA began establishing branches for African-Americans; in some cities, the $\mathrm{Y}$ also opened women's chapters. ${ }^{6}$ The organization's secretaries began to target working-class men-often of immigrant background-and promoted industrial paternalism that was to mitigate social conflicts. The $Y$ taught immigrant men English as a part of ongoing Americanization efforts; it also provided leisure activities and educational opportunities to the wearied men toiling in the new industrial order. ${ }^{7}$ All these turn-of-the-century innovations contributed to the growing popularity of the organization in the United States and facilitated the expansion of the $\mathrm{Y}$ abroad.

6 The YMCA owed its expansion into other continents to the boundless energy of the organization's secretaries such as John Mott or Paul Super. Super-who played a salient role in the activities of the YMCA in Poland-began his service to the $\mathrm{Y}$ by establishing 
branches of the organization in Asia. In the first decades of the twentieth century the $Y$ promulgated the Social Gospel in China and Japan, joining American missionary organizations in their civilizational and religious endeavors. ${ }^{8}$ Mott wholeheartedly supported the transfer of the $\mathrm{Y}$ to Russia where, as Miller argues, the YMCA was to contribute greatly to the preservation and expansion of Orthodox Christianity during the years of communism. ${ }^{9}$ In the interwar period, in its overseas activities the organization stressed sport and physical education that were winning over reluctant inhabitants of such territories as the Philippine Islands. ${ }^{10}$ Sport also became the driving force of the organization during its service to civilians and soldiers in Europe in the years of World War I.

7 The involvement of the $\mathrm{Y}$ in war-time assistance went back to the times of the Civil War when the organization cooperated with the newly established United States Christian Commission, providing stationary, newspapers, books and religious literature to soldiers and sailors. During the Civil War the Y began to operate mobile canteens that offered soldiers supplements to army rations; it was also mobile canteens that became a symbol of the organization's war aid in World War I Europe. During this global conflict the YMCA collaborated with local governments, offering service and relief to civilians and soldiers in such diverse countries and territories as the United States, France, Russia, Australia, or the Middle East. Spreading throughout the war-ridden world, the Y boosted the morale of soldiers and propagated its philosophy of a symmetrical development of young men. ${ }^{11}$

8 Soldiers of Polish descent met for the first time with the $\mathrm{Y}$ in France, while serving in the army of General Jozef Haller predominantly composed of young men recruited in the United States. At the beginning of 1919, five Y secretaries including the aforementioned Paul Super were transferred with Haller's Army to the recently reborn Poland. During the Soviet-Polish war of 1920, the YMCA ran several mobile canteens and built a number of shelters for Polish soldiers and officers. As in France or other war-torn European countries, in Poland the YMCA aimed at providing army men with educational activities and wholesome entertainment that were to divert young men's attention from indecent and immoral activities. ${ }^{12}$ A gradually growing group of American secretaries and their local collaborators served cocoa and offered reading and writing classes to illiterate soldiers who applauded "ciocia Imka" (Auntie Imka), as the organization was nicknamed in Poland. ${ }^{13}$

9 In post-war years the YMCA initiated in Poland a multi-dimensional program for moral and physical renewal of young men and teenage boys, aiding refugees, students and war prisoners. As American humanitarians and social workers were gradually withdrawing from the country, the Poles, with the help of the Americans, created their own organization that combined the overseas model with several local features. Establishing in 1922 the Polish YMCA, local and American leaders of the organization concentrated their activities in two main sectors. The first one was setting up municipal branches of the YMCA in the largest Polish cities: the official capital of the country, Warsaw; "the intellectual capital," Cracow; and "the industrial capital," Lodz. ${ }^{14}$ In the buildings that were being gradually erected in Polish metropolises, the Y offered vocational training, physical education as well as "decent" leisure. ${ }^{15}$

10 The second main activity of the Polish YMCA was the work among railroad workers from eastern frontier towns and cities. The YMCA served railroad workers, as the American Director of the Association Paul Super described it, during "a time of national 
emergency,"16 that is in the first half of the 1920s which was a period of intense political conflicts and social unrest, accompanied by the final settlement of the Polish borders and a post-war economic crisis. As the situation on the eastern border improved, the organization abandoned its railroad work in 1926.

Paul Super was the person particularly devoted to the Y's railroad work. In his writings Super, who made frequent visits to eastern Polish towns and cities, observed similarities between the Polish and American borderlands. Born in 1880 in Cincinnati, Super was a graduate of the University of Missouri who served in the YMCA throughout his life. Having worked for a few years in Oregon, he organized and directed the Y's work in Hawaii. With the outbreak of World War I, Super began training the organization's staff and was then transferred to Poland where he lived during the entire interwar period. ${ }^{17}$

In Twenty-Five Years with the Poles-the memoirs Super published in 1947, he openly admitted that he "loved the eastern frontier." 18 The Director of the Polish YMCA seemed to be particularly enchanted by Lvov and Vilnius, which he defined as "two Polish cities in every way and the main centers of western civilization in that part of eastern Europe." 19 Writing about their nearby territory, he added: "Between them... lies "the Kresy" or border-land, to me full of the reminders of our own western frontier, only ours was west, not east as in Poland." 20

A similar comparison between Polish and American frontiers may be found in an article published by Super in 1924 in the American periodical Railroad Men. The piece, included in the magazine for the American YMCA railroad industry members, was tellingly entitled "On Poland's Frontier." In it, Super commented: „The Polish frontier over toward Russia is real frontier. It reminds one of the less developed sections in our American prairies 25 years ago." ${ }^{21} \mathrm{He}$ also wrote:

[I]n the old Russian Poland, where the paw of the bear rested most heavily, civilization was and is sparse. There the great plain stretches far abroad like Western Kansas. The villages are widely separated, farm houses as we know them in America are never seen, and great forests and marshes make up mile after mile of the landscape with occasional open spaces, across which one can see for many miles. The physical character of the country is not the only reminder of America's wild west, for companies of bandits occasionally sweep across the Polish border, rob and kill, and return to Russia. ${ }^{22}$

Several features of the Polish frontier reminded Super of American borderland: the landscape, the settlements, as well as the population. What is striking and significant in Super's writings regarding Poland's eastern borderland is his usage of the term "civilization." During his upbringing and education in the United States, Paul Super was "soaked" with ideas and philosophies that referred to "civilization" and that used this concept to discuss racial and social relations in the United States and worldwide. In Super's writings one may see his intellectual debt to such American theorists and scholars as the anthropologist Lewis Henry Morgan or the psychologist and pedagogue G. Stanley Hall. ${ }^{23}$ Lewis Henry Morgan was known for what in his time was a seminal scientific theory delineating the "lines of human progress." According to Morgan, human societies and races developed in the process of evolution that began from the stage of savagery, and led through barbarism to the most advanced level of civilization. For Morgan and his American contemporaries, by the nineteenth century only a few human groups achieved the highest rung on the ladder of civilization. At the top of it, 
racial theorists situated Anglo-Saxons, placing other groups such as Slavs somewhere in between, and representatives of African and "Oriental" races at the very bottom. ${ }^{24}$

Interestingly, the concept of civilization was used also in another, very eminent piece of writing that described the situation on the frontier defined as "the meeting point between savagery and civilization." ${ }^{25}$ The latter phrase prominently featured in the seminal paper of Frederick Jackson Turner read during the assembly of the American Historical Association in 1893. The closing of the frontier line, as indicated in the 1890 census, was for Turner perilous for the future of the United States whose progress and development depended on the existence of western wilderness. "The frontier"emphasized Turner-"is the line of most rapid and effective Americanization." ${ }^{26}$ It was on the moving western frontier that the American character was being forged and a new breed of people being raised:

[t]he coarseness and strength combined with acuteness and inquisitiveness; that practical, inventive turn of mind... that restless nervous energy; that dominant individualism... these are traits of the frontier, or traits called out elsewhere because of the existence of the frontier. ${ }^{27}$

The theory and discourse of civilization as well as the prominent "frontier thesis" doubtless influenced Paul Super's diagnosis regarding the societal and political conditions on Poland's eastern frontier. If the "Kresy" were "full of the reminders" ${ }^{28}$ of the American western frontier, as Super stressed in his afore-quoted memoirs, was the process of forging a nation taking place also at the Polish eastern borderlands? Prior to World War I the "Kresy" belonged to tsarist Russia; in the 1920s in independent Poland a mixture of different nationalities and ethnicities populated them. In most places ethnic Poles constituted a minority, being outnumbered by Jews and White Ruthenians (Belarusians) in the north-east and by Jews and Ukrainians in the south-east. ${ }^{29}$ Paul Super's diagnosis of the situation on the Polish frontier pertained to what was a former Russian territory: the region in northeastern Poland with the cities of Vilnius, Bialystok, and Brzesc, inhabited at large by Jewish urban dwellers and Belarusian peasants. According to Super, on Poland's eastern borderlands the White Ruthenian peasants were being transformed into Polish citizens. The eastern Polish frontier was for the American Director of the YMCA "a meeting point between savagery and civilization," where borderland conditions facilitated the process of Polonization of Belarusian peasants.

"Before the war, White Ruthenian peasants were among the poorest and most ignorant in Europe," ${ }^{30}$ wrote Super in his memoirs. In "On Poland's Frontier," he presented a highly stereotypical description of the borderland peasantry: "the peasants who move into these villages and become common laborers are White Russians-a sturdy race but apparently of low intelligence and certainly representing a low state of culture." ${ }^{31}$ At the same time, Super observed that the frontier peasant was undergoing an evolution, transforming from a Russian serf to a Polish citizen. It was exactly the life on the frontier, or at the "meeting point between savagery and civilization," that expedited this alteration. As Super emphasized in Twenty-Five Years with the Poles: "He [the peasant] contrasts his present state with pre-war Russia and the Bolshevism only a few miles to the east, and daily becomes a better Polish citizen." ${ }^{32}$ That the male Belarusian peasant was on his way to becoming "civilized" was in part due to compulsory military training. According to Super, military education provided young men from the eastern frontier with the possibility to learn to read and write. The army experience also erased peasant ignorance. As a result of the frontier living and military training, the peasant 
was becoming a civilized, law-abiding Polish citizen who wished, quoting Super again, to "build a sty for his pig instead of keeping it at home" and to educate his brothers and sisters. ${ }^{33}$

The YMCA attempted to accelerate and to facilitate the Polonization of the eastern frontier and its rural population, perceiving Polishness as a signifier of a more advanced stage of civilization. A direct contribution of the American association to this process was the establishment of the YMCA railroad branches (ogniska) in the eastern frontier towns and cities. The idea to set up the ogniska came from Teodor Emil Landsberg, the president of the Vilnius railroad unit who at the beginning of the 1920s invited the YMCA to his company. In the early 1920s the YMCA established similar ogniska in such north-eastern frontier cities as Vilnius, Białystok, Brzesc, Pinsk, Baranowicze, and in many smaller towns. In fourteen YMCA railroad associations, about five thousand Polish railway employees found access to libraries and reading rooms, vocational courses and several social and educational programs that aimed at uplifting men's morale and providing them with amusement and recreation. In Vilnius, the YMCA opened a nursery for the railroad workers' children. ${ }^{34}$ Railroad associations were, however, first and foremost intended as centers of "Polish national culture" ${ }^{35}$ in territories where according to the YMCA leaders Western civilization was seriously imperiled.

This salient "civilizational" role of the railroad branches stemmed from a unique position of the railroad engineers and other technical employees. ${ }^{36}$ YMCA leaders emphasized the Polishness of the railway workers and defined them as "the best element of this population," "the preservers of culture," or "the local intelligentsia." ${ }_{37}$ As a scholar and YMCA leader Roman Dyboski argued, railroad workers were one of a few frontier forces that "elevated life, represented civilization, made for progress, and looked for a brighter future." ${ }^{38}$ Dyboski emphasized that the members of the YMCA railroad branches did not only maintain their own, that is Polish, culture, but also "performed a patriotic function of winning the less cultured and illiterate of the population to true Christian citizenship." ${ }^{39}$ This "less cultured and illiterate population" was, we can assume, the Belarusian peasantry undergoing a process of Polonization that implied democratic citizenship and Catholic religion.

YMCA's railroad work was not a typically Polish phenomenon as since the turn of the twentieth century the organization was establishing $Y$ railroad associations in the United States, though for different reasons than in Poland. In the American context, as Thomas Winter argues, Y programs for working class men were to "defuse workers' potential for labor unrest by involving them in a web of uplifting activities." ${ }^{40}$ In Poland a similar aim of preventing or resolving labor-management conflicts was adopted by the YMCA in Lodz, the biggest Polish industrial center in the interwar years where the $\mathrm{Y}$ was invited into factories and offered programs for local young male employees. ${ }^{41} \mathrm{On}$ the Polish frontier the purpose of setting up Y branches was different, however: the targeted railroad workers-enjoying a high social prestige as a local vocational elitedid not pose a threat but were seen in need of recreation and social welfare.

By founding its railroad branches on the Polish frontier the YMCA also recognized the cultural and political potential of the railroad stations that in the nineteenth and early twentieth century served a vital social role by helping establish order and maintain discipline in under-populated and "uncivilized" territories. As Jeffrey Richards and John MacKenzie argue in their acclaimed The Railway Station: A Social History, railroads 
and railway stations were unifying the nations and spurred economic growth and development, at the same time producing a new social elite of uniformed railroad employees. ${ }^{42}$ This function was of utmost importance in a newly reestablished Polish state that aimed at uniting the Kresy with the rest of its territory. Railroads symbolized progress and modernity that the young Polish state aspired to, and the railroad workers embodied order and discipline on the territories menaced by communism.

The narrative about the "Polish borderland" also reveals the YMCA's assumptions regarding Polish citizenship and the "Polish religion." Being an inherently Protestant organization, in Poland the YMCA emphasized its Catholic character and attachment to the Catholic Church despite the Catholic bishops' vehement criticism of the Y's activities and philosophy. ${ }^{43}$ The official policy of the Association allowed only Christians to become the members of the organization. The Y excluded Jews, whose presence in Poland Paul Super regarded as a "colossal problem." ${ }^{44}$ Jewish inhabitants of the "eastern frontier" are meaningfully omitted from the narrative created by Super and other Y leaders. It may be argued that the striking absence of Jews in Super's frontier writings helped the Director of the Polish YMCA to downplay the ethnic diversity of the eastern borderland and to present Belarusian peasants as a social class and not a national minority.

The Polonization of White Ruthenian rural dwellers which was taking place on Poland's eastern borderland is presented in Super's writings as an easy and smooth process that is fully and gladly embraced by Belarusian peasants. Super rather gently described this endeavor, stressing that "people are learning the Polish language, coming into the Catholic Church, thinking of themselves as Polish citizens, and in other ways creating in their own minds a mental state favorable to a normal life, settled political conditions, and a stable frontier." ${ }^{45}$ The Director of the Polish YMCA did not mention the fact that a vast majority of Belarusian peasants belonged to the Orthodox Church, as this omission allowed the religious difference between the colonizing Poles and Polonized White Ruthenians to be ignored. In Super's writings about the eastern frontier, Polishness implied Catholicism. Super erased Belarusian peasants' ethnic characteristics such as language or religion, apparently for the sake of presenting their transformation into Polish citizenship and identity as smooth. Super frankly admitted that the efforts of the YMCA were in this aspect congruent with the official policies of the reborn Polish state, stressing that "our rows of triangles is indeed but a thin line down the frontier, but the importance of their service is recognized by railroad workers, officials in the Ministry, and citizens in general who know the eastern border." ${ }^{46}$

Citizenship and religiosity are also crucial for identifying the last actor in Super's frontier puzzle, or a group allegedly representing savagery on the Polish frontier. In Turner's famous essay, on the American moving frontier this role was played by Native Americans portrayed as primitive "savages," in opposition to whom American identity and American character were being formed. Native Americans, as argues the cultural historian Alan Trachtenberg, were "the utmost antithesis to an America dedicated to productivity, profit, and private property" ${ }^{47}$-the traits that connoted the capitalist economy. For the proponents of the theories of civilization, Poland and native Poles also possessed their "civilizational Other," ${ }^{48}$ whose cultural Otherness became even more apparent after the events of 1917. In their view, Poland's frontier was a meeting 
point between Western, Christian, democratic, and capitalist "civilization" and its opposite: the eastern "barbarism" embodied by Soviet Russia.

In the writings of Paul Super and other YMCA leaders, Russia had represented oriental barbarism even before the time of communism. For the YMCA secretaries it was Bolshevism, however, that became the fullest embodiment of "eastern savagery." In the YMCA's view, Bolshevism functioned as "the most demoralizing force"; 49 and as "a plague that destroys everything," and "menace to all civilizations." ${ }^{50}$ The Association's revulsion from communism was augmented by its members' experiences during the Soviet-Polish war, when the YMCA aided Polish soldiers fighting against "bloodthirsty Bolsheviks killing women, children, and the aged." ${ }^{51}$ According to the YMCA War Work Secretary D.A. Davis, in 1920 the Poles were "called to stand between anarchy, as manifested to the east of them, and the western world. The battle is one that of the anti-Christian materialist social order and ordered progress represented in a Christian civilization." ${ }^{52}$

For the YMCA leaders, the winning of the war over Bolshevism in 1920 did not, however, bring Poland's civilizational mission to completion, especially in face of the acquisition of new eastern territories. Super and his collaborators sustained their belief in Poland as a civilizer of its eastern borderland throughout the interwar years. In 1937, after fifteen years spent in Poland, the Director of the YMCA Paul Super wrote in one of his reports: "eastern provinces should be defended from the Russian invasion; they must be strengthened against the Bolshevik propaganda, and their standard of civilization in the rural areas must be both raised and Polonized." ${ }^{33}$ However, in the late 1930s the YMCA no longer played a direct role in this "civilizational endeavor," as since 1926 it was focusing solely on its municipal branches. Nonetheless, the Association leaders spoke frequently about the peril of communism and strengthened antiBolshevism in the largest Polish cities. Paul Super adhered to the view that "Western civilization will either hold this country [that is Poland] and improve it or be pushed back by a lower culture ["oriental" Soviet "barbarism"].54 ***

As I have argued, American leaders of the Polish YMCA envisaged the Polish eastern borderland along the lines of the U.S. western frontier and thus treated it as a meeting point between savagery and civilization, as well as the territory where a new Polish citizenship was being forged. The railroad work that the YMCA initiated in the early 1920 s had in this context long-lasting political, cultural and civilizational ramifications. For YMCA leaders such as Paul Super or Roman Dyboski, the railroad workers from the eastern frontier personified civilization and were accorded a vital task of a cultural uplift of illiterate Belarusian peasants who were climbing the ladder of civilization. On the territories that had belonged to tsarist Russia and were now endangered by the Soviet propaganda, the YMCA and its railroad workers were to serve the role of the bulwark of Christianity, democracy, and capitalism: the concepts that denoted Western civilization. In the YMCA leaders' rhetoric, the bordering Soviet Russia connoted, on the contrary, "eastern barbarism," synonymous with primitivism, anarchism, antiChristian materialism and totalitarianism. ${ }^{55}$ Significantly, the goals that the Association intended to reach on the eastern frontier, such as the Polonization of Belarusian peasants or the taming of Bolshevism, corresponded with the national and international policies of Poland. 
YMCA's vision of social relations and the political situation in Poland's borderlands stemmed from the American frontier myth and the influential discourse of civilization that shaped the opinions of such $Y$ workers as Paul Super. In his narrative regarding the civilizing mission in the eastern borderlands the sizeable Jewish population of the region was completely ignored and the religious difference between Catholicism and Orthodox Christianity was erased. Although the Polish leaders of the YMCA such as Roman Dyboski largely shared Super's assumptions, the local Polish press, and probably the railroad workers themselves, regarded YMCA's eastern branches as cultural and educational centers serving engineers and conductors, and not as "civilizing spots" in the "eastern wilderness." In Polish press articles that described the Y initiatives for railroad workers, the narrative of the Polish frontier that filled Paul Super's writings is strikingly absent. ${ }^{56}$ The Y's eastern branches named in Polish as ogniska or "firesides" were to give "light and warmth" ${ }^{57}$ to wearied railroad workers who in fact constituted an advantaged group in the region, but who did not necessarily see themselves as civilizers or Polonizers.

Copeland, Jeffrey C. and Xu, Yan. "Introduction: Collaboration and Conflict: The YMCA at War." In The YMCA at War: Collaboration and Conflict during the World Wars, 1-16. Edited by Jeffrey C. Copeland and Yan Xu. Lanham. Maryland: Lexington Books, 2018.

Davidann, Jon Thares. A World of Crisis and Progress: The American YMCA in Japan, 1890-1930. Cranbury, NJ: Lehegh University Press, 1998.

Dyboski, Roman. The YMCA in Poland. New York: Foreign Committee Young Men's Christian Association of the United States and Canada, 1935.

Gems, Gerald M. The Athletic Crusade: Sport and American Cultural Imperialism. Lincoln, Nebraska: University of Nebraska Press, 2006.

Hall, G. Stanley. Adolescence: Its Psychology and Its Relation to Physiology, Anthropology, Sociology, Sex, Crime, Religion and Education. New York: D. Appleton and Company, 1904. Hopkins, C. Howard. History of the YMCA in North America. New York: Association Press, 1951.

Hübner, Stefan. "Muscular Christianity and the „Western Civilizing Mission”: Elwood S. Brown, the YMCA, and the Idea of the Far Eastern Championship Games." Diplomatic History 39, no 3 (2015): 532-557.

Jaroszewski, Julian, and Maciej Łuczak. „Kultura fizyczna w programach Łódzkiego Oddziału ZwiĄzku Młodzieży Chrześcijańskiej (YMCA) w latach 1920-2002.” Prace Naukowe Akademii im. Jana Długosza w CzĘstochowie. Kultura Fizyczna 13, no 2 (2014): 95-113.

Johnson, Elmer L. The History of YMCA Physical Education. New York: Association Press, 1979.

Kałamacka, Ewa. "Działalność Amerykańskiej Misji Wojskowej YMCA w Polsce w latach 1919-1922." In Z najnowszej historii kultury fizycznej w Polsce, vol. 5. Prace Naukowe Letniej Szkoły Historyków Kultury Fizycznej, 127-137. Edited by Bernard Woltmann. Gorzów Wielkopolski: Polskie Towarzystwo Naukowe Kultury Fizycznej, 2002.

Kałamacka, Ewa. “Działalność „Polskiej YMCA” zapowiedziĄ sportu dla wszystkich (1923-1939)." In Z tradycji wychowania fizycznego i sportu w czasach zaboru i II RP, 63-71. Edited by Stanisław Zaborniak i Paweł Król. Rzeszów: Wydawnictwo Uniwersytetu Rzeszowskiego, 2008.

Kałamacka, Ewa. "Działalność polskiej YMCA w dziedzinie wychowania fizycznego i sportu." Wychowanie Fizyczne i Sport no 4 (1989): 77-90. 
Kuźma-Markowska, Sylwia. Dziecko, rodzina i płeć w amerykańskich inicjatywach humanitarnych i filantropijnych w II Rzeczypospolitej. Warszawa: Wydawnictwa Uniwersytetu Warszawskiego, 2018.

Ladd, Tony, and James A. Mathisen. Muscular Christianity: Evangelical Protestants and the Development of American Sport. Grand Rapids: Baker Books, 1999.

Lupkin, Paula. Manhood Factories: YMCA Architecture and the Making of Modern Culture. Minneapolis and London: University of Minnesota, Press 2010.

Marcus, Joseph. Social and Political History of the Jews in Poland, 1919-1939. Berlin, New York, Amsterdam: Mouton Publishers, 1983.

MĘdrzecki, Włodzimierz. Województwo wołyńskie 1921-1939. Elementy przemian cywilizacyjnych, społecznych i politycznych. Wrocław: Zakład Narodowy im. Ossolińskich, 1988.

Men and Women Adrift: The YMCA and the YWCA in the City. Edited by Nina Mjagkij and Margaret Ann Spratt. New York and London: New York University Press, 1997.

Miller, Matthew M. The American YMCA and Russian Culture: The Preservation and Expansion of Orthodox Christianity, 1900-1940. Lanham, Maryland: Lexington Books, 2012.

Mjagkij, Nina. Light in the Darkness: African-Americans and the YMCA, 1852-1940. Lexington: University Press of Kentucky, 2015.

Morgan, Lewis Henry. Ancient Society, or the Researchers in the Lines of Human Progress from Savagery through Barbarism to Civilization. New York: Henry Holt and Company, 1877. Muscular Christianity: Embodying the Victorian Era. Edited by Donald E. Hall. Cambridge: Cambridge University Press, 1994.

Putney, Clifford. Muscular Christianity: Manhood and Sports in Protestant America, 1880-1920. Cambridge, Mass. and London: Harvard University Press, 2001.

Richards, Jeffrey and John MacKenzie. The Railway Station: A Social History. Oxford: Oxford University Press, 1986.

Rose, William J. and Paul Super. The Polish Young Men's Christian Association: Facts for Friends in America. New York: Associated Press 1927.

Service with Fighting Men: An Account of the Work of the American YMCA in World Wars. New York: Association Press, 1922.

Smith, Erika Cornelius. "The YMCA and the Science of International Civil Statecraft in Post-World War I Czechoslovakia," In The YMCA at War: Collaboration and Conflict during the World Wars, 101-122. Edited by Jeffrey C. Copeland and Yan Xu. Lanham, Maryland: Lexington Books, 2018.

Super, Paul. Twenty-Five Years with the Poles. New York: Paul Super Memorial Fund, 1950. Tlustý, Tomáš. "A Brief Comparison of Physical Education and Sport within the Czechoslovak and Polish YMCA in Interwar Years." Prace naukowe Akademii im. Jana Długosza w CzĘstochowie. Kultura Fizyczna 16, no. 3 (2017): 29-45.

Tomaszewski, Jerzy. Zarys dziejów Żydów w Polsce w latach 1918-1939. Warszawa: Wydawnictwa Uniwersytetu Warszawskiego, 1990.

Trachtenberg, Alan. The Incorporation of America: Culture and Society in the Gilded Age. New York: Hill and Wang, 1982.

Turner, Frederic Jackson. "The Significance of the Frontier in American History." In The Frontier in American History. New York: Henry Holt and Company, 1920.

Vandenberg-Daves, Jodi. "The Manly Pursuit of Partnership between the Sexes: The Debate over YMCA Programs for Women and Girls, 1914-1933.” The Journal of American History 78, no. 4 (1992): 1324-1346. 
Winter, Thomas. Making Men, Making Class: The YMCA and Workingmen, 1877-1920. Chicago: The University of Chicago Press, 2002.

Wolff, Larry. Inventing Eastern Europe: The Map of Civilization on the Mind of the Enlightenment. Stanford, CA: Stanford University Press, 1994.

Xing, Jun. Baptized in the Fire of Revolution: The American Social Gospel and the YMCA in China, 1919-1937. Cranbury, NJ: Lehegh University Press, 1996.

Zald, Meyer L. and Patricia Denton. "From Evangelism to General Service: The Transformation of the YMCA." Administrative Science Quarterly 8, no 2 (1963): 214-234. Żebrowski, Piotr T. "Symbol of Symmetrical Development: The Reception of the YMCA in Poland." The International Journal of History of Sport 8, no 1 (1991): 96-110.

\section{NOTES}

1. Tomáš Tlustý, „A Brief Comparison of Physical Education and Sport within the Czechoslovak and Polish YMCA in Interwar Years," Prace naukowe Akademii im. Jana Długosza w CZĘstochowie. Kultura Fizyczna 16, no 3 (2017): 29-45; Piotr T. Żebrowski, "Symbol of Symmetrical Development: The Reception of the YMCA in Poland," The International Journal of History of Sport 8 no 1 (1991): 96-110; Erika Cornelius Smith, "The YMCA and the Science of International Civil Statecraft in Post-World War I Czechoslovakia," in The YMCA at War: Collaboration and Conflict during the World Wars, ed. Jeffrey C. Copeland and Yan Xu (Lanham, Maryland: Lexington Books, 2018), 101-122; Julian Jaroszewski and Maciej Łuczak, „Kultura fizyczna w programach Łódzkiego Oddziału ZwiĄzku Młodzieży Chrześcijańskiej (YMCA) w latach 1920-2002," Prace Naukowe Akademii im. Jana Długosza w CzĘstochowie. Kultura Fizyczna 13, no 2 (2014): 95-113; Ewa Kałamacka, „Działalność „Polskiej YMCA” zapowiedziĄ sportu dla wszystkich (1923-1939)," in Z tradycji wychowania fizycznego i sportu w czasach zaboru i II $R P$, ed. Stanisław Zaborniak i Paweł Król (Rzeszów: Wydawnictwo Uniwersytetu Rzeszowskiego, 2008), 63-71; Ewa Kałamacka, „Działalność polskiej YMCA w dziedzinie wychowania fizycznego i sportu," Wychowanie Fizyczne i Sport no 4 (1989): 77-90.

2. Matthew M. Miller, The American YMCA and Russian Culture: The Preservation and Expansion of Orthodox Christianity, 1900-1940 (Lanham, Maryland: Lexington Books, 2012).

3. C. Howard Hopkins, History of the YMCA in North America (New York: Association Press, 1951), 101-404; Meyer L. Zald and Patricia Denton, "From Evangelism to General Service: The Transformation of the YMCA," Administrative Science Quarterly 8, no 2 (1963): 214-234.

4. Hopkins, History of the YMCA, 452-593; Elmer L. Johnson, The History of YMCA Physical Education (New York: Association Press, 1979), 45-220; Paula Lupkin, Manhood Factories: YMCA Architecture and the Making of Modern Culture (Minneapolis and London: University of Minnesota Press, 2010), 111-136.

5. Clifford Putney, Muscular Christianity: Manhood and Sports in Protestant America, 1880-1920 (Cambridge, Mass. and London: Harvard University Press, 2001); Tony Ladd and James A. Mathisen, Muscular Christianity: Evangelical Protestants and the Development of 
American Sport (Grand Rapids: Baker Books, 1999); Muscular Christianity: Embodying the Victorian Era, ed. Donald E. Hall (Cambridge: Cambridge University Press, 1994).

6. Nina Mjagkij, Light in the Darkness: African-Americans and the YMCA, 1852-1940 (Lexington: University Press of Kentucky, 2015); Men and Women Adrift: The YMCA and the YWCA in the City, ed. Nina Mjagkij and Margaret Ann Spratt (New York and London: New York University Press, 1997; Jodi Vandenberg-Daves, „The Manly Pursuit of Partnership between the Sexes: The Debate over YMCA Programs for Women and Girls, 1914-1933," The Journal of American History 78 no 4 (1992): 1324-1346.

7. Thomas Winter, Making Men, Making Class: The YMCA and Workingmen, 1877-1920 (Chicago: The University of Chicago Press, 2002).

8. Jon Thares Davidann, A World of Crisis and Progress: The American YMCA in Japan, 1890-1930 (Cranbury, NJ: Lehegh University Press, 1998); Jun Xing, Baptized in the Fire of Revolution: The American Social Gospel and the YMCA in China, 1919-1937 (Cranbury, NJ: Lehegh University Press, 1996).

9. Miller, The American YMCA and Russian Culture.

10. Stefan Hübner, "Muscular Christianity and the „Western Civilizing Mission”: Elwood S. Brown, the YMCA, and the Idea of the Far Eastern Championship Games," Diplomatic History 39, no 3 (2015): 532-557; Gerald M. Gems, The Athletic Crusade: Sport and American Cultural Imperialism (Lincoln, Nebraska: University of Nebraska Press, 2006).

11. Copeland and Xu, "Introduction: Collaboration and Conflict: The YMCA at War," in: The YMCA at War, 2-4.

12. The Kautz Family YMCA Archives, Minneapolis [henceforth: YMCA Archives], YMCA of the USA Records, Records of YMCA International Work in Poland [henceforth: YMCA in Poland], Bibliographical Records, Talton to Terrill, box 202, folder 2, A.S. Taylor, The YMCA in Poland," The Red Triangle no 4, 1921, 179-181; Service with Fighting Men: An Account of the Work of the American YMCA in World Wars (New York: Association Press, 1922), 458-467.

13. YMCA Archives, YMCA in Poland, Bibliographical Records, Talton to Terrill, box 202, folder 2, A.S. Taylor, "The YMCA in Poland," The Red Triangle no 4, 1921, 179-181; Service with Fighting Men, 458-467; Ewa Kałamacka, “Działalność Amerykańskiej Misji Wojskowej YMCA w Polsce w latach 1919-1922," in Z najnowszej historii kultury fizycznej w Polsce, vol. 5. Prace Naukowe Letniej Szkoły Historyków Kultury Fizycznej, ed. Bernard Woltmann (Gorzów Wielkopolski: Towarzystwo Naukowe Kultury Fizycznej, 2002), 127-137.

14. Paul Super, Twenty-Five Years with the Poles (New York: Paul Super Memorial Fund, 1950), 41.

15. Sylwia Kuźma-Markowska, Dziecko, rodzina i płeć w amerykańskich inicjatywach humanitarnych $i$ filantropijnych w II Rzeczypospolitej (Warszawa: Wydawnictwa Uniwersytetu Warszawskiego, 2018), 312-340.

16. Super, Twenty-Five Years, 66.

17. Polish Institute of Arts and Sciences of America Archives, New York City [henceforth: PIASA], Paul Super Papers [henceforth: Super Papers], folder 6, News from the field: Retirement of Paul Super (1946).

18. Super, Twenty-Five Years, 118.

19. Super, 30.

20. Super, 30.

21. Super, “On Poland's Frontier," Railroad Men June 1924, 157.

22. Super, 157. 
23. Lewis Henry Morgan, Ancient Society, or the Researchers in the Lines of Human Progress from Savagery through Barbarism to Civilization (New York: Henry Holt and Company, 1877); G. Stanley Hall, Adolescence: Its Psychology and Its Relation to Physiology, Anthropology, Sociology, Sex, Crime, Religion and Education (New York: D. Appleton and Company, 1904).

24. Morgan.

25. Frederic Jackson Turner, "The Significance of the Frontier in American History" in The Frontier in American History (New York: Henry Holt and Company, 1920), 3.

26. Turner, 4.

27. Turner, 37.

28. Super, Twenty-Five Years, 30.

29. Jerzy Tomaszewski, Zarys dziejów Żydów w Polsce w latach 1918-1939 (Warszawa: Wydawnictwa Uniwersytetu Warszawskiego, 1990); Joseph Marcus, Social and Political History of the Jews in Poland, 1919-1939 (Berlin, New York, Amsterdam: Mouton Publishers, 1983); Włodzimierz MĘdrzecki, Województwo wołyńskie 1921-1939. Elementy przemian cywilizacyjnych, społecznych i politycznych (Wrocław: Zakład Narodowy im. Ossolińskich, 1988).

30. Super, Twenty-Five Years, 64.

31. Super, "On Poland's Frontier," 158.

32. Super, Twenty-Five Years, 65.

33. Super, 65.

34. Super, 31; William J. Rose and Paul Super, The Polish Young Men's Christian Association: Facts for Friends in America (New York: Associated Press, 1927), 2-3; YMCA Archives, YMCA of Poland, box 1, folder 7, Report of D.A. Davis Visit to Poland, Feb 1-8, 1925, s. 4; YMCA Archives, YMCA of Poland, box 1, folder 5, Poland 1924, s. 7-8.

35. Roman Dyboski, The YMCA in Poland (New York: Foreign Committee Young Men's Christian Association of the United States and Canada, 1935), 8.

36. Dyboski, 8.

37. Super, "On Poland's Frontier," 158.

38. Dyboski, The YMCA in Poland, 8.

39. Super, "On Poland's Frontier," 158.

40. Winter, Making Men, Making Class, 65.

41. Kuźma-Markowska, Dziecko, rodzina i płeć, 354-356.

42. Jeffrey Richards and John MacKenzie, The Railway Station: A Social History (Oxford: Oxford University Press, 1986).

43. Kuźma-Markowska, Dziecko, rodzina i płeć, 322-324; Żebrowski, “The Symbol of Symmetrical Development," 105-107.

44. YMCA Archives, YMCA of Poland, box 8, folder 5, Poland and the Polish YMCA in March 1937, by Paul Super.

45. PIASA, Super Papers, folder 10, Eastern Poland as Seen by Paul Super, 3.

46. PIASA, Super Papers, folder 10, Eastern Poland as Seen by Paul Super, 4.

47. Alan Trachtenberg, The Incorporation of America: Culture and Society in the Gilded Age (New York: Hill and Wang, 1982), 37.

48. Larry Wolff, Inventing Eastern Europe: The Map of Civilization on the Mind of the Enlightenment (Stanford, CA: Stanford University Press, 1994), 82-83.

49. YMCA Archives, YMCA of Poland, box 7, folder 7, The Polish Y.M.C.A., The Permanent Establishment Project of the Polish YMCA, Warsaw 1928.

50. YMCA Archives, YMCA of Poland, box 1, folder 1, Report no 2 on YMCA War Work in Poland, D.A. Davis, 11. 
51. YMCA Archives, YMCA of Poland, box 1, folder 1, Report no 2 on YMCA War Work in Poland, D.A. Davis, 11.

52. YMCA Archives, YMCA of Poland, box 7, folder 6, D.A. Davis, War work of the Young Men's Christian Association in Poland and Checho-Slovakia, 10.

53. YMCA Archives, YMCA of Poland, box 8, folder 5, Poland and the Polish YMCA in March 1937, by Paul Super, 3.

54. Super, "On Poland's Frontier," 157.

55. Super, "On Poland's Frontier," 157-159; Dyboski, The Y.M.C.A. in Poland, 7; YMCA Archives, YMCA of Poland, box 7, folder 6, D.A. Davis, War Work of the Young Men's Christian Association in Poland and Checho-Slovakia, 10.

56. “Z życia 'ognisk kolejowych.' Zadania i praca ognisk kolejowych.” Wileński PrzeglĄd Artystyczny, 8-9 (1924): 15; „Y.M.C.A. (Od własnego korespondenta).” Wieczorny Kurier Grodzieński 102 (April 13, 1935): 7.

57. “Z życia 'ognisk kolejowych,” 15.

\section{ABSTRACTS}

This article seeks to present and analyze one of the aspects of the work of the Young Men's Christian Association (YMCA or Y) in interwar Poland: the initiatives for railroad workers from eastern frontier towns and cities. Focusing on the efforts that the organization undertook on the territory commonly referred to as the Polish borderlands (Kresy), I show that for the leaders of the $\mathrm{Y}$ the work among the railway employees was of utmost political and civilizational importance. There were several reasons why the YMCA became involved in the railroad work on the eastern Polish borderlands. One of them was the looming threat of communism from neighboring Russia, another-the American Y leaders' mythic perceptions of the U.S. moving frontier, which prompted them to adapt the American discourse on civilization to the Polish political and social situation. Using archival documents and recollections of Americans involved in the Y's activities on the eastern Polish frontier I demonstrate how the perception of the Polish borderland by the Y's secretaries was greatly influenced by myths deeply embedded in American culture. Drawing on the contemporary Polish press reports as well as writings of local collaborators of the YMCA, I also describe the reaction of Polish public opinion to the Y's undertakings on the Polish frontier.

\section{INDEX}

Keywords: Young Men's Christian Association, interwar Poland, communism, civilization, frontier 
AUTHOR

\section{SYLWIA KUŹMA-MARKOWSKA}

Sylwia Kuźma-Markowska is Assistant Professor at the American Studies Center, University of Warsaw. She specializes in twentieth-century social and cultural history of the United States and Poland. Her areas of research include women's and gender history, transnational history of reproduction and public health, and history of social movements. 